A F R I C A N M I L I T A R Y S T U D I E S ・ Volume 3

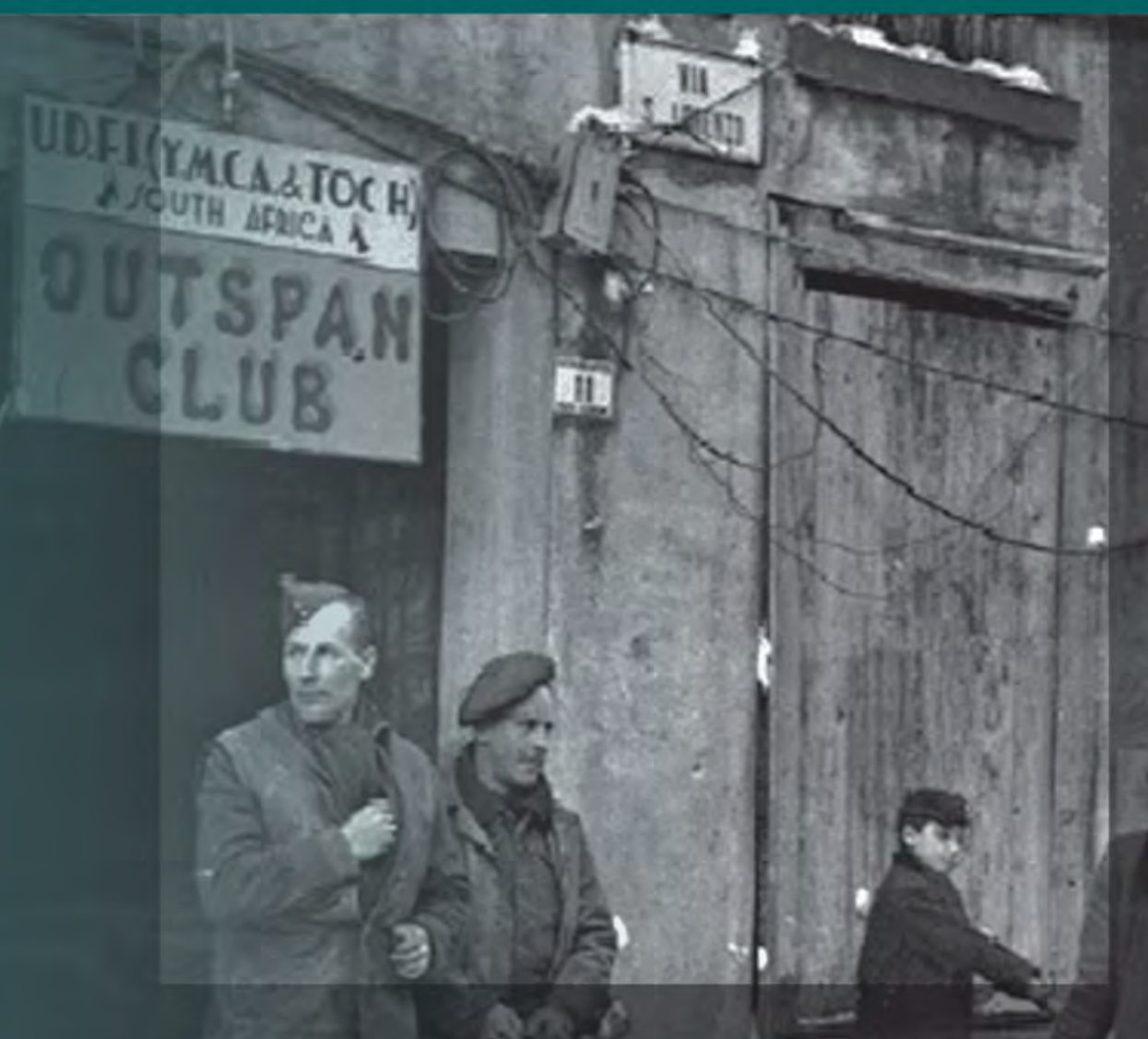

Sights, Sounds,

Memories

South African Soldier Experiences

of the Second World War 


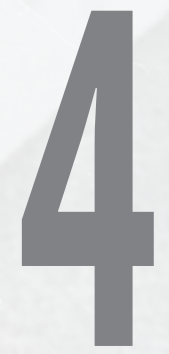

\section{'A PROTRACTED PICNIC'? THE WARTIME EXPERIENCE OF ARTHUR BINTLIFF IN MADAGASCAR, 1942}

\section{Evert Kleynhans}


A drastic shift was observed in the academic study of war during the twentieth century. As a result, the traditional field of military history was broadened to include several new approaches to the historical study of warfare. The recording of the personal experience of war, especially as a key component of the broader framework of war and society, proved particularly popular. Traditionally, the South African deployments to East Africa, North Africa and Italy during the Second World War have received the bulk of local historical attention. Unfortunately, the deployment of the $7^{\text {th }}$ South African Infantry Brigade (SA Inf Bde) to Madagascar remains largely ignored. The chance discovery of a series of wartime letters, written by Arthur Bintliff, offers a rare glimpse into the personal experience of a South African soldier during one of the forgotten campaigns of the war. The Bintliff correspondence provides an unprecedented account of the thrill of combat, the monotony of daily military routine, the leisure-time of soldiers, and the experience of wartime Madagascar in general. By analysing the Bintliff correspondence this chapter offers a rare in-depth, discussion on the South African military experience during the Madagascar campaign.

\section{INTRODUCTION}

Samuel Hynes argued that war narratives are a distinctive literary kind. In The Soldier's Tale Hynes argued that mankind generally displays a curiosity about war. He contends that it is often easier to respond to one man and his 'war' rather than to try and comprehend the overwhelming statistics associated with modern warfare - especially in terms of the vast numbers of soldiers, battles and casualties. For Hynes it was important to 'understand what war was like, and how it feels ... [and to] seek the reality in the personal witness of the men who were there'. ${ }^{1}$ In order to construct the so-called soldier's narrative, however, the wartime experiences of individuals first need to have been recorded. Hynes clearly distinguishes between two broad categories of the soldier's narrative. To him, the distinction is underpinned by differing needs - first to report, and second to remember. Accounts that fall into the reporting category consist of letters, diaries and journals that were kept by soldiers as the war unfolded. These are naturally extremely valuable historical sources, particularly since they offer a sense of immediacy and frankness in the recording of the personal experience of war. The second category is comprised of memoirs, which are compiled from the wartime letters, diaries and journals that soldiers kept. They are generally far more reflective in nature, since they are written years after the actual experience of war. Moreover, memoirs give a selective overview of 'what the young self did, what happened to him, what changed him'. ${ }^{2}$

In South Africa the soldiers' narratives of the Second World War consist mainly of memoirs written by white servicemen, who saw action with the Union Defence 
Force (UDF) in East Africa, North Africa and Italy. These published memoirs provide an unrivalled account of life in the UDF during the war and they touch on several key aspects such a social interaction, morale, discipline, combat and leisure time. The works are largely autobiographical in nature and written from a decidedly bottom-up perspective that focuses on the experience of the individual soldier. As a mnemonic community, the authors were mainly rank and file soldiers, with some accounts written by non-commissioned officers and officers. These works stand in stark contrast to the traditional autobiographies written by senior and general officers, which are marked by a distinct top-down approach in terms of analysis. In these latter accounts the voice of the ordinary servicemen is largely unheard. ${ }^{3}$ Unfortunately, the voices of South African servicewomen, along with the UDF's black, Indian and Coloured volunteers, however, remain unrecorded despite the ground-breaking work of historians such as Louis Grundlingh. ${ }^{4}$

The South African historians writing more broadly on the Second World War have also not really engaged with the whole notion of the soldier's narrative as proposed by Hynes. While the works of Albert Grundlingh, Neil Roos, Karen Horn, James Bourhill, Gustav Bentz and Kevin Greenbank ${ }^{5}$ to some extent may be exceptions, this trend unfortunately continues to prevail. A possible reason for this may indeed be the paucity of relevant personal correspondence, diaries and journals available at South African archival depots. The fact that South Africa also does not have a central repository where relevant material may be deposited adds to the woes. Neither the Department of Defence (DOD) Archive in Pretoria nor the Ditsong National Museum of Military History in Johannesburg are suitable repositories for various reasons. Moreover, both of these institutions preserve little to no relevant material documenting the individual experiences of South African soldiers during the Second World War.

Historians interested in writing on the individual South African soldier's experience thus face something of a conundrum when trying to locate relevant source material. While it is possible to obtain access to private collections, these are generally hard to come by. ${ }^{6}$ The lesser-known archives maintained by South African regimental associations, such as that of the Natal Carbineers in Pietermaritzburg for instance, may also contain relevant source material. The private correspondence, diaries and journals of former soldiers are often deposited at these archival depositories for preservation. Gaining access to these collections, however, may prove problematic at times, with bureaucratic red tape often hindering access for researchers.

The historiography on South African participation in the Second World War remains problematic, as the major focus is still on the three big deployments of the UDF to East Africa, North Africa and Italy. The deployment of the $7^{\text {th }}$ SA Inf Bde to Madagascar remains understudied, despite the wealth of primary material housed at the DOD Archives. Internationally, the campaign has also not received much attention, particularly since it was considered as somewhat of a sideshow of the major campaigns. 
The most noteworthy publications on the campaign are those of Martin Thomas ${ }^{7}$ and John Grehan, ${ }^{8}$ while South African sources on the campaign are decidedly scant. The works of the Union War Histories Section, André Wessels, Deon Fourie and Jackie Grobler are also worth noting. ${ }^{9}$ Their publications, for the most part, fall into the category of traditional military histories, but they do serve as a point of departure for an investigation of a much understudied aspect of South African military history.

To date there has been no detailed study of the personal experience of the South African troops deployed to Madagascar. The chance discovery of a series of wartime letters in the DOD Archives, however, offers a rare glimpse into the personal experience of a South African soldier during one of the forgotten campaigns of the war. The letters in question were written by Arthur Bintliff between July and November 1942, while he was deployed to the theatre as a Private serving with the Pretoria Highlanders. The Bintliff correspondence indeed fits into Hynes's framework for war narratives. It is decidedly autobiographical in nature, set within a historical context, and presented as something akin to travel writing. ${ }^{10}$ Moreover, the Bintliff correspondence also provides a rare lens for an analysis, mainly because the personal experiences of the South African troops deployed to Madagascar have never truly been recorded. Consequently, the Bintliff correspondence to some degree acts to provide the 'missing voice' on the South African soldier's experience of the campaign. The Bintliff correspondence is therefore a useful tool through which to investigate key aspects of the soldiers' experience, such as the military operating environment, leisure time utilisation, morale, discipline and the thrill of combat. By analysing the Bintliff correspondence, this chapter offers a rare, in-depth discussion on the wartime experience of a South African infantryman during the Madagascar campaign. In doing so, it addresses an evident gap in the broader historiography on South African participation in the war.

\section{BINTLIFF - AN ORDINARY SOUTH AFRICAN INFANTRYMAN?}

Any good war story has its main protagonist. In the case of this chapter, it is Arthur Thomas Bintliff - a somewhat ordinary South African of English decent. Little is known about his background, apart from scraps of information that could be gleaned from his personnel file housed at the DOD Archives in Pretoria. Generally speaking, such personnel files contain a wealth of information of both a personal and militaryadministrative nature. At a casual glance, however, an individual personnel file is riddled with military jargon and acronyms that, to the untrained eye, may essentially render the file 'impenetrable'. Fortunately, when these obstacles are surmounted, either through help from archival staff or through sheer persistence, the proverbial treasure trove of information on an individual's wartime service is revealed. 
Each personnel file contains valuable genealogical data as well as key information detailing an individual's military service. From a genealogical point of view, some of the most important information in a personnel file is contained in the attestation papers. Attestation papers generally provide key insights into dates of birth, places of birth, next of kin, physical addresses, information on dependants, and so forth. More importantly, personnel files contain vital information that can be used to extrapolate an individual's military service. A host of documents, from attestation and discharge forms, to record cards and charge sheets, can be used to reconstruct a soldier's wartime journey. Moreover, when the information in the personnel files is substantiated with supplemental archival material, such as unit war diaries, for instance, a fairly complete picture can be constructed of an individual's wartime experience. This approach was adopted in the case of Bintliff in a determined attempt to reconstruct the soldier's missing narrative.

Born in Johannesburg on 26 March 1908, Bintliff in all likelihood grew up in the former Transvaal, where he completed peacetime training in the UDF. We know that he was of average height and build, with dark hair, brown eyes and a somewhat dark complexion. His personnel file states that he was part of the Active Citizen Force during the latter half of the 1930s. In this capacity he served as a trooper with the Imperial Light Horse based in Johannesburg. Prior to the outbreak of the war, Bintliff worked as a printer for The Natal Witness, a Pietermaritzburg newspaper. His experience in the print industry would prove extremely beneficial during the South African deployment to Madagascar. We also know that Bintliff was married and that his wife resided at Tweespruit in the Orange Free State, before later on moving back to Johannesburg during the war. All told, he had the makings of an ordinary, white, working-class South African of the time. ${ }^{11}$

After South Africa declared war on Germany on 6 September 1939, thousands of young men volunteered for military service in the UDF. The reasons for joining were varied, with some men being driven by patriotism, a sense of moral duty, a desire for adventure, and, above all, a yearning to play an active role in the broader war effort to defeat fascism. Others, however, saw military service merely as a means to secure somewhat steady employment and social mobility, with the added benefits of regular pay, a roof over their heads, medical care and the promise of three square meals a day. ${ }^{12}$ Bintliff, however, only attested into the UDF on 15 July 1940 , nearly a month after the Italian entry into the war. His reasons for enlisting remain unclear, though it is safe to assume that he answered the general call to arms like so many other ordinary white South Africans - be it for King and Country, or simply duty, honour and the promise of adventure. After reporting at the Police Depot in Pretoria, Bintliff underwent a period of intensive military training. By December he was posted to the $1^{\text {st }}$ Battalion Pretoria Highlanders, where he was assigned to a platoon of A Company - his regimental home for the next two years. ${ }^{13}$ 
Throughout 1941, and for the first few months of 1942, the Pretoria Highlanders had the mundane duty of guarding one of the wartime internment camps in the Union, at Jagersfontein in the Orange Free State, while some troops were also deployed to South West Africa on garrison duty. This period proved rather uneventful for Bintliff - the only noteworthy incidents being a disciplinary issue relating to disregarding unit standing orders that cost him 14 days in the detention barracks, and his hospitalisation due to a severe bout of haemorrhoids. ${ }^{14}$

In June 1942, however, Bintliff's wartime journey suddenly changed. The Pretoria Highlanders, which formed part of the $7^{\text {th }}$ SA Inf Bde of the $3^{\text {rd }}$ South African Infantry Division (3 SA Div), were earmarked to deploy to Madagascar as part of the larger Allied operation to subjugate the island. On 12 June the Pretoria Highlanders, along with the rest of the brigade, embarked on the SS Empire Trooper in Durban destined for Madagascar. After a rather unexciting seaward journey, they disembarked at Diego Suarez, on the northern tip of Madagascar, on 28 June. For the next four months or so Bintliff and his compatriots would call Madagascar their temporary home, yearning for the opportunity to prove their metal in actual combat. The majority of the South African troops, save for a select few, were not involved in any ground combat operations during the deployment, however, and for the most part settled into the somewhat leisurely role of wartime occupation. Bintliff was fortunate enough to be a part of two separate ground combat operations and wrote rather extensively about his experiences. By 12 November, with the subjugation of Madagascar all but complete, the Pretoria Highlanders embarked on the SS Nieuw Amsterdam from Diego Suarez destined for the Middle East. ${ }^{15}$

After disembarking at Suez on 21 November, the $7^{\text {th }}$ SA Inf Bde were deployed on garrison duties in Egypt until such time as the brigade was amalgamated with the $1^{\text {st }}$ SA Inf Bde. The establishment of the $6^{\text {th }}$ South African Armoured Division (6 SA Armd Div) in 1943 meant that the mainstay of the former infantry divisions would be repurposed to form the nucleus of the new armoured division. ${ }^{16}$ By January 1943 Bintliff was taken off strength from the Pretoria Highlanders, and posted to the general infantry pool of the South African Armoured Corps. For the next year or so Bintliff would call Egypt home, and once more the only noteworthy incidents during this period appear to be a similar disciplinary issue as before that cost him 25 days in the detention barracks, and another stint in hospital with a recurring case of haemorrhoids. ${ }^{17}$

By July Bintliff was taken on strength with the First City Regiment, a unit that had also seen service in Madagascar. That October the First City Regiment was married up with the Cape Town Highlanders to form the First City/Cape Town Highlanders (FC/CTH). The FC/CTH was one of a host of amalgamated units of the newly established 6 SA Armd Div. After an intense period of training and conversion at Khatatba in the Egyptian desert, 6 SA Armd Div deployed to Italy during March 1944. ${ }^{18}$ Little is, however, known of Bintliff's deployment to Italy. 
Apart from a brief stint in hospital in May 1945, we know that he was repatriated in September, and earmarked for demobilisation after some well-deserved leave. In February 1946 Bintliff was finally discharged from the UDF, after a total of five years and 192 days of wartime service. With a host of campaign medals to his name, Bintliff returned to civilian street to once more take up employment as a printer - this time with the Goldfields Press in Johannesburg. ${ }^{19}$

At face value Bintliff's wartime service appears to fit the pattern of an ordinary South African infantryman. His military service was indeed regular enough for him to disappear amongst the thousands of faceless South African soldiers who served in the UDF during the war. When the focus is narrowed down to his deployment to Madagascar with the $7^{\text {th }}$ SA Inf Bde, however, Bintliff is no longer just an ordinary South African infantryman. He is in fact extraordinary, mainly because he is one of a select few servicemen who in one way or another recorded their wartime experiences in Madagascar. Using Hynes's framework, and employing Bintliff as a lens, the South African experience of the Madagascar Campaign can be better understood.

\section{THE SOUTH AFRICAN DEPLOYMENT - BRIEF HISTORICAL CONTEXT}

The possibility of the Japanese occupation of Madagascar prompted the British defence planners to take action against the Vichy-controlled island in 1942. The Allies contended that if the Japanese occupied Madagascar, they would have ready access to the strategic harbour of Diego Suarez - situated roughly halfway along the strategic sea route between the Indian subcontinent and the Cape of Good Hope. This would have a detrimental effect on Allied shipping in the Indian Ocean, as Japanese naval forces would then have a free hand to attack Allied naval and merchant shipping along the entire east coast of Africa. ${ }^{20}$

Winston Churchill, the British Prime Minister, was of the opinion that 'a Japanese air, submarine, and/or cruiser base at Diego Suarez would paralyse our whole convoy route both to the Middle and Far East', ${ }^{21}$ Jan Smuts, the South African prime minister, also considered Madagascar to be the key to safety in the Indian Ocean, especially regarding merchant shipping. He felt that a strategic decision about Madagascar's occupation was required sooner rather than later, and that the mere capture of Diego Suarez alone would not deter possible Japanese aggression. In his opinion, the entire island, including the ports of Majunga and Tamatave, needed to be taken over. Churchill subsequently decided to carry out the occupation of Madagascar. ${ }^{22}$

On 5 May 1942 the British Force 121 landed in Vichy-controlled Madagascar and successfully seized Diego Suarez two days later. The primary task of Force 121 was initially only to capture and hold the strategic naval base of Diego Suarez in the extreme north of the island in the hope of reducing the risk of a Japanese invasion. 
From the outset Smuts argued that the mere occupation of Diego Suarez would not suffice and that the entire island needed to be liberated from Vichy control. Smuts, who always advocated for the active deployment of South African troops, offered the $7^{\text {th }}$ SA Inf Bde to the British defence planners for the purpose. After some hesitation, and being ever wary of Smuts' sub-imperialism in the region, the British agreed to the deployment of South African troops. ${ }^{23}$

On 25 June the first wave of troops of the $7^{\text {th }}$ SA Inf Bde disembarked at Diego Suarez. Commanded by Brig G.T. Senescall, the Brigade comprised the First City Regiment, Pretoria Regiment and Pretoria Highlanders, and was supported by a squadron of armoured cars, an artillery field regiment, as well as a field company of sappers and other ancillary units. The Brigade's headquarters was established at Sakaramy near Antsirane in the vicinity of Diego Suarez. After settling down in their new billets, the soldiers soon started preparing defensive positions. They had the important task of defending the general area around Diego Suarez against a possible Japanese invasion and a Vichy French counterattack. In due course the South African infantry battalions were deployed further inland around the area of Ambilobe, thereby extending the defensive perimeter around Diego Suarez further south. The South African troops generally settled into a peaceful occupation task, despite the fact that Smuts continued to lobby for the full-scale occupation of the island. Fortunately for Smuts, the unexpected Japanese submarine attacks on shipping in the harbour of Diego Suarez worked in his favour. ${ }^{24}$

By the beginning of August, after a considerable amount of discussion and consultation, the British Chiefs of Staff finally decided to move ahead and occupy the entire island. The General Officer Commanding East Africa Command, Lt Gen Sir William Platt, assumed overall command of a series of complicated operations aimed at conquering the island. The ensuing offensive operations could hardly be regarded as serious warfare, since Vichy resistance proved only nominal. That being said, the operational conditions in Madagascar proved arduous, particularly because of the unforgiving climate, difficult terrain and a taxing disease ecology. The major offensive operations were conducted by the $29^{\text {th }}$ British Inf Bde and 22 nd East African Bde, who after advancing on and capturing Majunga, conducted a major overland advance towards the capital Tananarive..$^{25}$

Unfortunately, the mainstay of the South African troops played no major part in the final offensive operations that were launched during September. Apart from the armoured cars that led the advance towards the capital and took part in the only serious fighting of the campaign, the combat experience of the majority of South African troops was extremely limited. The First City Regiment successfully advanced from Sakaramy to Maromandia, despite a number of road blocks and broken bridges that hampered their movements. Elements of the Pretoria Regiment, backed up by some armoured cars, took part in the bloodless occupation of Vohemar, Sahambava and 
Antalaha on the east coast. An under-strength company of the Pretoria Highlanders took part in the occupation of the isle of Nossi Bé, after which they supported the operations against Maromandia. By the end of September Tananarive was successfully occupied, after which two companies from the Pretoria Regiment took part in an operation in the extreme south after landing at Tulear. On 4 November the Vichy Governor, Armand Annet, surrendered, with an armistice signed the next day. By the beginning of December all South African troops had been withdrawn from Madagascar, bringing to an end their brief deployment. ${ }^{26}$

\section{ADVENTURE, ROUTINE AND MORALE}

Arthur Bintliff arrived in Madagascar towards the end of June. After settling into their new billets at Sakaramy, elements of the Pretoria Highlanders were posted south to reinforce the Allied position at Ambilobe. Fortunately for Bintliff, his company was allocated to take part in this operation, and by the beginning of July the men arrived in the vicinity of Ambilobe. Bintliff and his comrades had no choice but to make peace with the monotony of daily military routine in a forward position. They were to occupy this position until the beginning of August, when they were called back to the battalion that was headquartered at Concession Grignon near Antsirane (see Map 1). ${ }^{27}$

The month or so that Bintliff was deployed to the proverbial 'frontline', including his experience of soldiering in general, was succinctly captured in the first letter that he wrote home on 31 July. One immediately gathers that by the end of July the South African troops had not received any mail, which had a direct impact on their morale. The troops indeed longed for any bit of news from the Union. ${ }^{28}$ Unknown to the rank and file, the postal dilemma affected all Allied troops on the island - a matter that was dictated by the availability for shipping and return cargoes more than anything else. In fact, the South African authorities could do little to alleviate the matter. ${ }^{29}$ Nevertheless, for Bintliff and his comrades the situation proved rather dire:

Still not a word from you! I hope my letters are reaching you sometimes, but oh, how we long for news of home. They talk about morale, and let the chief ingredient therein go to blazes, with never a word of explanation. ${ }^{30}$

It is evident that the novelty of deployment to the frontline soon wore off. Bintliff reported that his section undertook active patrols only on every second or third day, but maintains that it was still far better than doing guard duty at Jagersfontein. Patrolling proved to be a rather monotonous affair, however, as the enemy was ever elusive. Intermingled with their patrol and guard duties, the men also undertook regular training exercises, firing of their defensive plans, and compulsory weapon maintenance. 
The South Africans soon realised that patrol duty afforded them the ability to explore the local countryside and mingle with the local civilians around Ambilobe. ${ }^{31}$

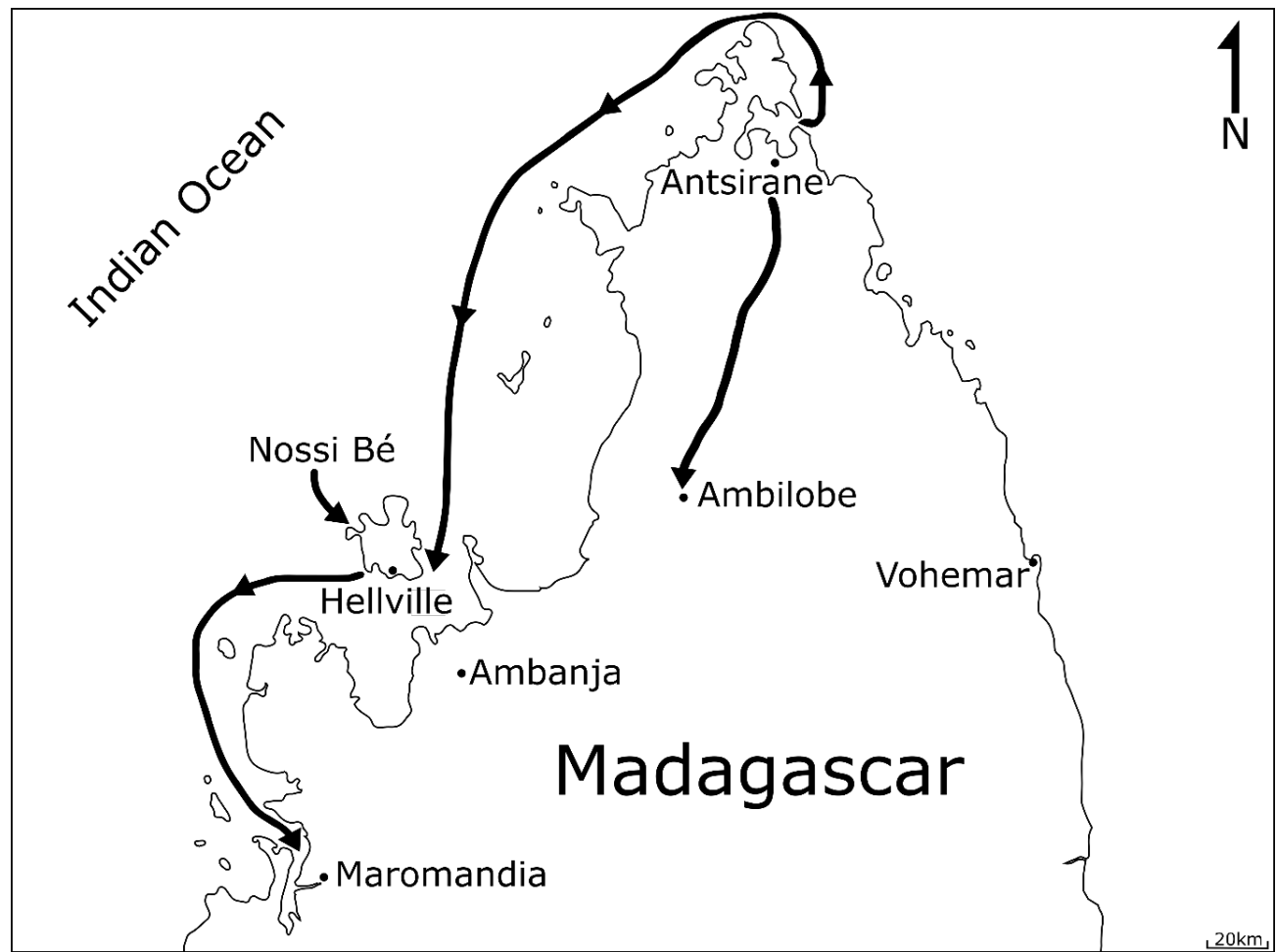

MAP 1: Principal Movements Of Arthur Bintliff During The Madagascar Campaign

During their adventures the men soon became aware of the fact that there seemed to be almost no animals and very few birds around the Madagascar countryside. They did, however, encounter a large number of snakes, and Bintliff also makes mention of the numerous crocodiles in the Mahavavy River. According to Bintliff, the crocodiles were quite stubborn, so much so 'that you have to use an anti-tank rifle to move them.' ${ }^{32}$ Bintliff remarked that Madagascar would have been a marvellous paradise had it not been for the over-supply of mosquitoes. The high amount of rainfall that Madagascar received annually naturally compounded the issue and led to a drastic increase in the number of mosquitoes. Bintliff described the mosquitoes as being fearful creatures, and that even the utmost precautions they took did not help, as they still found their way into your clothes by the hundreds. Fortunately, up to then there had not been a single case of malaria amongst the Pretoria Highlanders. The troops were, however, required to take quinine twice a day as a precautionary measure against malaria. ${ }^{33}$ 


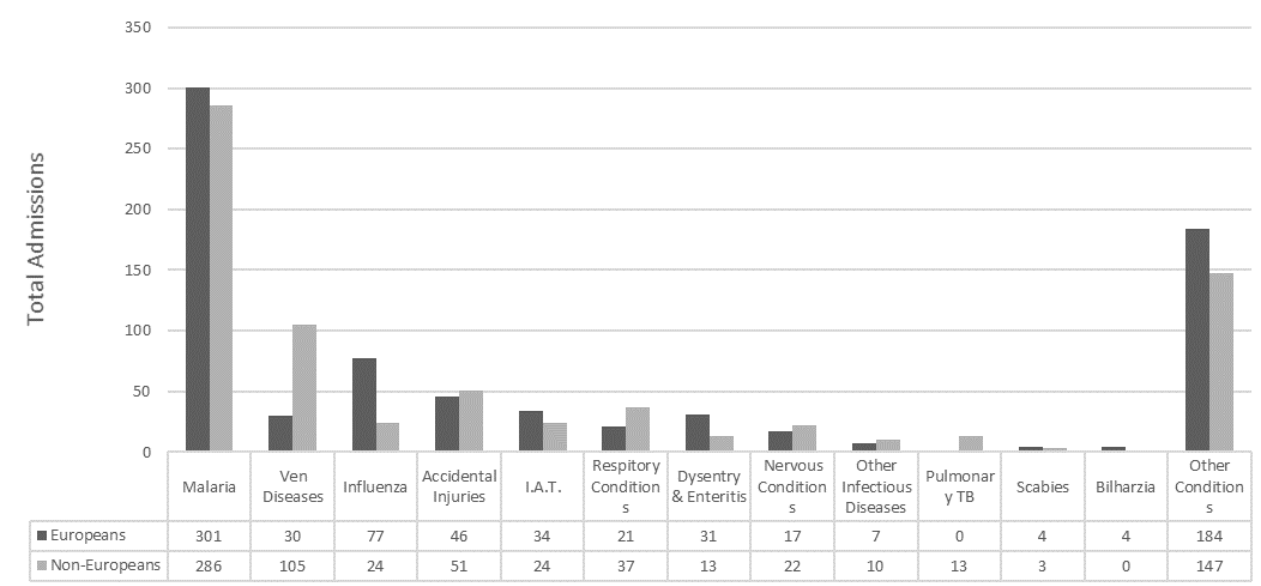

GRAPH 1: Hospital admissions of South African troops during the Madagascar campaign, June to November 1942.

Source: DOD Archives, UWH (Civil), Box 344, File Campaign in Madagascar, Medical Aspects of the Campaign in Madagascar.

In the following months, however, malaria would take an increasing toll amongst the South African troops. At least 13\% of all Union Defence Force troops on the island contracted malaria whilst deployed to Madagascar, despite the fact that the deployment took place outside of the usually accepted epidemic period of January to July (see Graph 1). The majority of the infections occurred during the active operational period, with a total of 222 cases of malaria reported during the major offensive operations undertaken throughout September and October. Nevertheless, infections continued at a steady rate throughout the campaign, with at least 21 cases of malaria reported per week. Despite stringent anti-malarial measures, as well as the provision of suppressive quinine, malaria infections amongst the troops remained rather high. In an effort to address the matter, the Director of Medical Services dispatched an expert malariologist to the $7^{\text {th }} \mathrm{SA}$ Inf Bde. This officer had to provide advice on the placement of camps and basic personal hygiene, as well as sensitise combat officers regarding the care of their men while deployed. Despite the high incidence of malaria amongst the troops, the Madagascar campaign was heralded as a relative victory for the medical and hygiene service. They were particularly lauded since, through their concerted efforts, a large body of troops was kept healthy in a tropical area riddled with diseases over a period of four and a half months. This is illustrated by the fact that of the 4570 South African troops deployed to Madagascar, only 1491 medical cases were admitted to 19 South African Field Ambulance over the period June to November 1942 (see Graph 1). ${ }^{34}$

As with all deployed soldiers over the ages, Bintliff had a lot to say about food. Luckily, the deployed troops were able to supplement their rations by buying extra foodstuffs, especially fresh produce, from the local population. In fact, for 'frontline' soldiers, 
Bintliff contended, they were being fed magnificently - far better than what they were used back at the battalion headquarters. The system of 'buying in' local supplies led to one rather comical event when some of the cooks went to a local village to source fresh produce:

Piet Bierman introduced him as the 'chef', under the impression that this was French for cook, whereas it is only the English. They came back with terrific stories of how the Malgasch got a move on wherever they went, bowing and scraping and fixing the whole village up for inspection, etc. I laughed till I cried, because they were dumbfounded at the respect paid to cooks - till I told them he had been impersonating the G.O.C. himself. Not only is 'Chef' the word for 'Chief', but the French have spent years teaching the locals to respect 'le chef', which they properly did! Anyway, they got hundreds of eggs and vegetables, etc., practically for nothing. ${ }^{35}$

As their time on the frontline drew to an end, Bintliff and his comrades were rather hesitant to return back to the battalion headquarters - where 'everyone is being led a devil of a life'. ${ }^{36}$ The apparent freedom of life on the frontlines naturally held a certain amount of appeal for the troops, especially since it was far removed from the humdrum of regimental life under the watchful gaze of the Adjutant and the Regimental Sergeant Major. As Bintliff and his compatriots readied themselves to leave Ambilobe, he could not help but question if they would ever have the opportunity to engage in actual combat and fire their weapons in anger. As his company got ready to leave their forward area, Bintliff summed up their brief deployment and their initial experience of Madagascar: 'all we have to describe is the protracted picnic, with plenty of discomforts and annoyances, in a hot country ... and that sums up our activities in this part of Madagascar. ${ }^{37}$

By the time Bintliff wrote his second letter home on 11 August, his company had returned to Concession Grignon near Antsirane. The return back to battalion had been a rather rude awakening for the men of A Company. Their new daily routine proved extremely unpopular, especially the mandatory stand-to before dawn and the regular firing of their defensive fire-plan. It took Bintliff some days to complete writing his second letter home. He complained that after returning from firing their defences, he seldom had any energy left to continue his correspondence. The fact that he had to stand duty every second night added to his woes, particularly since it disturbed his sleep. To Bintliff it seemed that all they ever did was 'wash, shave, breakfast, clean rifle and boots for an inspection at 07:30, march out, dig all day, march home, wash and prepare for duty. Same thing the next day. You sleep the next night if there are no alarms. ${ }^{38}$

Unsurprisingly, the deteriorating food and washing situation, and the ever-present howling wind, soon led to Bintliff describing his new billet as a rather horrible place. It is thus somewhat evident that when soldiers undergo a period of apparent 
discomfort, they often develop a new appreciation of home and all the comforts that come with it. Bintliff was no different:

You can imagine how I long for home and proper grub and a bit of comfort! And what joy our parcels bring. The eats never can be made to last more than a couple of days, but taste like the food of the gods. Yes, we have very many totally unnecessary annoyances, and no comforts - and no water! However, if we manage to survive all this, plus what war itself may bring, it certainly will have taught us to appreciate our homes and people! ${ }^{39}$

Whilst Bintliff and his company were deployed to Ambilobe, he wrote an article for a popular South African newspaper column at the time called Stoep Talk. In the article he described their deployment to the forward areas. Bintliff's pre-war employment with The Natal Witness, though not as a reporter, must have stood him in good stead. The result of the publication of the article was an instant boost to the morale of his company. Bintliff was appreciative that his relatives back home had submitted the article for publication, and basked in his instant fame:

I'm frightfully glad you sent it in - officers, sergeants-major and half the Company had the cutting within an hour or so .... and my stock seems to have risen a point or two. Funny how the power of the Press sticks. A good many things in the cutting were quite a good reflection, others were very funny to read! ${ }^{10}$

In his third letter home, written on 16 August, it is evident that Bintliff's morale had once more started to wane. He complained of the iniquities and vicissitudes that he and his comrades had to endure since arriving back at battalion - especially the unforgiving wind, lack of water, sweltering heat, occasional rain, and their rudimentary living conditions. He was, however, wary of not divulging too much information, for fear of his letters being censored: 'I could tell you some amazing stories of chaos, disorganisation on a grand scale, anecdotes of our officers, and things about military life ... that would sure shock you ... the whole ruddy outfit is appalling - and that's praising it!' ${ }^{41}$

One particular incident involving the Quartermaster, a certain Captain Baard, is noteworthy. The incident highlights the level of frustration amongst Bintliff and his comrades, especially with regards to over-zealous officers. To them, Baard signified everything that was wrong at battalion, and he at once became the subject of some unwelcome attention from the men:

... [he is] under the impression that a quartermasters' job is to prevent anyone, even officers, in the Regiment from getting any kit, or if, by some accident, someone gets something, to see that it does not fit him. Last night the fellow on duty at Quarter Stores saw Baards' canvas bath outside his tent - so he put his 
bayonet through it! Last week Baard had a British battle dress outfit made for him by a tailor in Antsirane - it was pinched within an hour of delivery! Now he does not know whether to have a guard or not! Up to now our objectives have been mainly stores but now Baard is the object. Some time ago somebody threw a bucket of water over his bed at scoff-time! ${ }^{42}$

Fortunately for Bintliff and his comrades, life back at battalion also brought with it some perks. On a number of occasions the South Africans were allowed a town pass, and were free to explore Diego Suarez and it surroundings. They were very impressed by the sheer size and beauty of the bay, but less impressed by the town of Antsirane. To them it was 'just a little too stinky for real romanticism'. ${ }^{43}$

Their journeys into Antsirane once more brought the South African troops into close contact with the local population. ${ }^{44}$ In his fourth letter home, written on 20 August, Bintliff hints at the fact that despite being used to racial segregation back in the Union, he and his comrades relished at the opportunity to interact with the local population. Their interaction with the local women proved most interesting, particularly since they yearned for female company. Racial segregation and their own inherent conservatism rather conveniently disappeared: 'we had dusky tropic beauties, childish prattle and all, usually to do with our washing, but sometimes just making friendly calls!' ${ }^{45}$ Moreover, despite the fact that their interactions with the local population seemed to have been very cordial, Bintliff described them as being very friendly, quite dirty, rather unsanitary, and being completely without any military spirit. He was also convinced that the Vichy French had wasted a lot of time, money and trouble in trying to turn their locally raised recruits into an efficient fighting force. ${ }^{46}$

By the beginning of September, when Bintliff wrote his next letter home, his prospects had somewhat changed. Fortunately, his pre-war employment now paid dividends. During the Allied occupation of the greater Diego Suarez area, the need arose to establish a local newspaper for propaganda purposes. The Evening Pioneer was thus born, with Bintliff assigned as its sub-editor. It is hardly surprising that he appreciated his new posting, as it meant a welcome break from the monotony and boredom of life back at battalion. Moreover, his new posting also meant new billets, a far cry from his previous digs. When on occasion Bintliff visited his compatriots back at battalion, he was reminded of his good fortune:

When I do go out there, am I pleased with my nice job, and my fine billet. I have been organising things and am now possessed of a marble-topped table, a bed stuffed with a sackful of the softest kapok, a feather pillow ... and wouldn't exchange my corner of the room for a dozen fine tents. ${ }^{47}$ 
The change in scenery and daily routine, had a profound impact on Bintliff's apparent morale. This is evident in the general tone of his writing and the positive way in which he describes his new surroundings. Also, it is almost the first time in which Bintliff commented on the beauty of Madagascar in his letters home as well as some indication that he started appreciating his new surroundings:

One amazing thing we have here are the lovely evenings. Most of the little dorp, soldiers and all, gather [at] about four o'clock ... to watch [the sunset]. The whole sky, the mighty bay and the sea to the horizon are a blazing vivid mass of hue and tone and solid colour.You can almost feel it. I defy the hardest heart to stand there and fail to thrill a little at the warmth of the spectacle, the magnificent sweeps of the brush of the Master, and the size and beauty incredible of the farsweeping background. So dies the Diego Suarez day. ${ }^{48}$

\section{COMBAT - THE MEASURE OF A MAN?}

At long last we've done it! We have been in action - successful action - twice since I wrote last. And many and many a thing has happened: thrilling, nervewracking, splendid things. Our years of inglorious life have been justified by our recent crowded hours - hours crowded with unforgettable experience, with many moving sights and sounds, with so much beauty, and thrill and excitement, that it will remain engraved in my mind for a mighty long time. ${ }^{49}$

Bintliff started his penultimate letter home, with these words. His excitement at finally having had the opportunity to deploy on an actual combat mission is difficult to hide. After nearly three months of inactivity, monotony and fluctuations in morale, Bintliff and his company were selected to take part in the series of final Allied operations aimed at subjugating the entire island. They were, however, extremely fortunate, being the only company from the Pretoria Highlanders to take part in a combat operation during the campaign. The target for their first operation, Operation Esme B, was a small island off the west coast of Madagascar called Nossi Bé, which was still under the control of Vichy forces (see Map 1). This, however, meant that the South Africans would have the dubious honour of being the first known group of their countrymen to be involved in an amphibious assault operation. Up to this stage of the war the South African soldiers had been used to fighting across bush, desert and jungle terrain. It was never envisaged that Union soldiers would ever storm a beach as part of a larger amphibious assault. Fortunately the South Africans were accompanied by a group of experienced Royal Marines. ${ }^{50}$

The prospect of going into actual combat, however, proved extremely daunting for Bintliff and his comrades. They were acutely aware of the fact that the Nossi Bé operation would provide the long-sought opportunity to prove their worth under fire. 
It would also, to some extent, vindicate the years they spent away from the frontlines. Bintliff describes both the general excitement and nervousness amongst the men:

We had never been in action, or even seen action before. We had spent inglorious years guarding the prisoners which more fortunate fellows had captured. We had marched around and about the barbed wire of internment and prisonerof-war camps till the barbs had stuck into the very beings of us and thoroughly embittered us.

But now - now we were to justify the kilt in which we had swaggered so often. Swaggered until some less fancily-dressed soldier asked us where we'd been. Sometimes they asked us if it were a war or a costume-ball we intended to grace [with our presence]. These remarks cut deep. But now the game was on.

Can any ordinary man, going to his first scrap, fail to feel a certain plumbing of the depths - a buoyancy and poise, plus a tingling of the scalp, a braced eagerness, a singing in his veins, a combination of joy and sadness, of high delight and zest, tempered with a little fear, a little sorrow - a kaleidoscopic surge of emotion excitable only in the rarest of mortals by any other motive? Certainly, none of our little band had a soul so dead. ${ }^{51}$

Once the South Africans boarded their troop transport, the HMS Manxman, their nerves tightened and excitement intensified. After receiving the orders for the assault, Bintliff and his comrades readied themselves for their short trip towards Nossi Bé. Under the cover of darkness, the naval force approached the island. Before the landing craft were lowered from the boat, the guns of the HMS Manxman engaged a number of predetermined military targets on the island:

Suddenly, dramatically, like hell let loose, a mighty tongue of devilish, vivid, ethereal flame tore at the satin folds of the night. A murderous, splitting stab of thunder roared its way through the silence. Two big guns had reared, barked their warning, and set back on their haunches.

What letters, in what language, can convey the tremulous, vibrant glory of a naval barrage at night? For ten long ages, ten minutes by the clock, the guns spat and stabbed at the dark ... their missiles hurtled to a shore only 400 yards from us, blasting suspected gun positions, carefully avoiding the direction of the town. Our object was to capture the place intact and undamaged. We sought no civilian life or property.

Then came the thrill of an answer from the shore. We were under enemy fire! A short-lived, stuttering answer it was, damned immediately by our light armament. ${ }^{52}$

After the naval guns had opened up and silenced the enemy positions, the landing party readied themselves for the final assault. In the eerie silence the South Africans readied themselves for the next stage of the operation - the final beach assault. In his description of the ensuing events, Bintliff captures both the harrowing and comical nature of the enterprise: 
Is there any transport operation more uncomfortable, more disturbing to one's peace of mind ... than clambering 30 feet or so from the deck of a tall warship to a bobbing lifeboat, by a crazy-acting Jacob's ladder, enshrouded the while by night as black as Egypt's, and laden like a prize pack mule?

After your first enterprise herein you might swear by the beards of all the Prophets that there is not. But you would be wrong. It would soon enough be revealed to you that the reverse operation ... was infinitely more threatening, more soul-destroying.

The accomplishment may not look so awkward, its successful outcome may not be in such immediate doubt, when you watch the Royal Marine going up ahead of you. But, believe me, this is a manoeuvre definitely in the category of things that must be experienced to be appreciated. Definitely.

We were the first Springbok troops to be used in an assault-landing party, and, for the soul's repose of all other Springboks, may we be the only ones. ${ }^{53}$

After a successful beach landing, the combined force of Royal Marines and Pretoria Highlanders headed for their respective objectives. The final opposition encountered, however, proved negligible, and by daybreak all objectives had been accounted for. According to Bintliff, it only took '[a] few grenades thrown wildly, some automatic fire, here and there a ticklish place, and by daylight the town was ours'. ${ }^{54}$ Once the action had died down, the occupiers could take stock of the town. Bintliff, whose morale was still extremely high, once again noted the sheer beauty of his new surroundings. The fact that the town had been spared from destruction, and coupled with the fact that their combat experience and had been all but negligible, with no casualties sustained, may have influenced his appreciation: 'The town is miscalled Hellville - it should have been Paradiseville. The whole island is beautiful, but this little place is a tropical dream. ${ }^{55}$

The sojourn in Hellville was extremely brief. Two nights later, the combined force of Royal Marines and Pretoria Highlanders embarked on a further offensive operation. The force was earmarked to execute a further amphibious operation along the west coast of the Madagascar, this time in support of the overland operation by the First City Regiment against Maromandia. It was envisaged that the amphibious force would envelop Maromandia from the south, thereby forcing the enemy to either stand and fight or simply surrender (see Map 1). After having to go through the arduous process of re-embarkation, Bintliff and his compatriots were once more transported south by HMS Manxman. After the naval force arrived in the vicinity of their designated landing area, the assault force was transported upstream through the mouth of a mighty river. ${ }^{56}$

The amphibious assault force, however, was constantly aware of their exposed position in the naval landing craft while they travelled up the river. As a result, the troops constantly scanned the river banks for any signs of the enemy. After an uneventful journey, the combined assault force was disembarked nearly 24 miles from their final objective. In order to close the distance between themselves and the objective, the assault 
force proceeded with a forced march of French Foreign Legion proportions - at least according to Bintliff:

What happened was simply this: we marched.And how we marched! We marched till we were dead from the neck down, till our bodies were nothing but a big floating pain compounded of all the small pains we had first felt from the various tortured points of our anatomy, till our heads were all the physique we were conscious of - our heads, carried along on a big horrible grinding pain.

First, after a mile or two of cross-country, it is only the soles of your feet beginning to feel a bit warmish, then they get hotter, and you find yourself wishing you had worn your other boots after all. Then your calves, or maybe your instep, bring you some sharp reminder of its presence. Then the utility pouches start to knock hell out of your thighs. Then your back starts - haversack, water bottle, bayonet, every 'accoutrement' combines with webbing, rifle, Bren pouches to make an arsenal of torture to rack you, squeeze you, stab you and burn you.

Your mind is in purgatory. The inferno produces a train of visions, all on the same theme: foaming quarts of cold lager in frosty glasses. You can hear the ice tinkle. Cups of tea, gallons of tea - real tea, mind you, not Army tea. The beach at Durban in your scrappy abbreviated trunks. The cold drink stalls in Pritchard Street. But on you plod, your water bottle long ago empty of its sultry fluid. ${ }^{57}$

By dusk Bintliff and his weary comrades reached their objective. Stragglers, however, continued to arrive throughout the night and well into the next morning. The Royal Marines, it seems, were not too hindered by the overland march, with most of them completing it in running shoes. The spirit and rivalry with the Royal Marines were also crucial in lifting the spirits of the South Africans. It is, however, very interesting to note that the South African troops had weapon bearers attached to them for a part of the march. Perhaps they had grown somewhat complacent and accustomed to the peaceful occupation duties of the previous few months - so much so that they were completely unprepared for the physical rigours of actual offensive operations. Nevertheless, no time could be wasted, and the assault force immediately began to prepare defensive positions. After an uneventful night, the assault force spent the next morning consolidating their positions and readying themselves for an impending attack. This attack, however, never materialised. The Allied pincer movement had caught the Vichy French force near Maromandia completely off-guard, forcing them to surrender. This brought to an end Bintliff's second combat operation - though in hindsight it was combat only in the broadest of definitions. ${ }^{58}$

Upon their return from the Maromandia operation, Bintliff and the rest of his company returned to Hellville, where they assumed garrison duties. In his final letter home, written on 20 October, one senses that Bintliff's morale had once more started to wane. After the excitement of the Nossi Bé and Maromandia operations had passed, and the monotony of daily routine and camp life returned, the South Africans soon found themselves with little to do to while away the time. Apart from another stint 
at newspaper work - this time establishing a paper on Nossi Bé - Bintliff's general mood dropped again. In his letter home he once more complains about the climate, food and mosquitoes. One sense too that Bintliff tries to defend their recent combat deployment, as he was unhappy with what had appeared in the newspapers in the Union. In a definite attempt to vindicate their experience of combat, he provides some rather stern criticism on the 'nonsense' being reported in the Union:

\begin{abstract}
We are not 'living like fighting cocks' ... nor are we having wonderful times on the beaches with tons of comforts, etc., some people may be having such luck - I hope they are. The $7^{\text {th }}$ Brigade is camped in a barren area where a continuous gale blows, with 0.5 gallon of water a day, or flat ration and we've never seen a home comfort, except once a month with luck from our own homes. Also though there was little bloodshed, there was fighting and we are not 'playing at war'. We took the Island, but are not lying back yet. Half of us are sick. There is no leave and no amusement. We are not grousing more than usual, but I wish the writers in the Union knew the difference between a war and a picnic ... Thank heaven I was in the thick of it and know it all first-hand. ${ }^{59}$
\end{abstract}

As October was drawing towards an end, the South African troops started picking up rumours that they would next deploy to the Middle East. In due course the men started undergoing desert warfare training. Bintliff, however, realised how fortunate he had been to be part of the only combat deployments of the Pretoria Highlanders during the campaign. By early November the remaining Vichy French forces had formally surrendered, and over the course of the next month the South African troops were withdrawn and redeployed to Egypt. Bintliff's correspondence ends rather abruptly at this point. He does, however, offer some final thoughts that speak to the soldiers' experience of war:

What have the lords of war next on the list for us? And will there always be the same joyful endings, the smiling faces of all one's comrades? May God defend the right.

I would urge every man who can to try these experiences for himself. If not for his convictions, then for his education. If he has innards, if he calls himself a man, then the ordeal of fire, the risks of war in our cause will lend his character a grandeur that will walk with him all his days.

Only in the theatre of war are these ennobling tragedies played, and you must be one of the actors.

And now that we have Tananarive, and their country and capital are ours, I hope we collect together all the Quislings, fifth columnists, gossip columnists, tablewater mongers (of a certain brand) and especially those pro-Nazi French pigs of the foulest motives who would sacrifice their country and their soul even to the yellow-bellied swine - because they think the Axis will win and hope to escape punishment in the punitive massacre which would follow.

Collect them, and march them all to the coast, before the rains, carrying all their $\underline{\text { kit! }}{ }^{60}$ 


\section{CONCLUSION}

The Bintliff correspondence provides a unique insight into a South African soldier's personal experience of the Madagascar campaign. For the most part the South African troops were deployed on guard and garrison duties while in Madagascar. For Bintliff and his comrades, these period of inactivity - marked by many discomforts and annoyances - were nothing more than a 'protracted picnic'. Unsurprisingly, the morale of the South African troops waned considerably during these periods, especially because of the irregularity of mail arriving from the Union. During the time that Bintliff deployed to the frontline and on active combat operations, the rise in his morale was evident in the letters that he wrote home. With the rising morale, there was also a renewed appreciation of the natural beauty of Madagascar. When the combat operations ceased, however, the morale amongst the troops once more dropped - and the feeling of being on a 'protracted picnic' once more sank in. 


\section{Endnotes}

$1 \quad$ S Hynes, The Soldier's Tale: Bearing Witness to Modern War (London: Pimlico, 1997), p xii.

2 Hynes, The Soldier's Tale, $\mathrm{p}$ xiv.

3 J Black, Rethinking Military History (Abingdon: Routledge, 2004), pp 35-36.

4 See for instance LWF Grundlingh, 'The Participation of South African Blacks in the Second World War' (Randse Afrikaanse Universiteit: PhD thesis, 1974).

5 See for instance A Grundlingh, 'The King's Afrikaners? Enlistment and Ethnic Identity in the Union of South Africa's Defence Force during the Second World War, 1939-45', The Journal of African History, vol. 40, no. 3 (1999), pp 351-365; N Roos, Ordinary Springboks: White Servicemen and Social Justice in South Africa, 1939-1961 (Aldershot and Burlington, Ashgate, 2005); K Horn, South African prisoner-of-war experience during and after World War II: 1939 - c.1950 (Stellenbosch University: PhD thesis, 2012); JF Bourhill, "Red Tabs" Life and death in the 6th South African Armoured Division, 1943-1945' (University of Pretoria: PhD thesis, 2014); G Bentz, 'Fighting Springboks - C Company, Royal Natal Carbineers: From Premier Mine to Po Valley, 1939-1945' (Stellenbosch University: MMil thesis, 2013); K Greenbank, "'You chaps mustn't worry when you come back": Cape Town soldiers and aspects of the experience of war and demobilisation, 1939-1953' (University of Cape Town: MA thesis, 1995).

6 S Morillo and MF Pavkovic, What is Military History? (Cambridge: Polity, 2018), pp 120-123.

7 M Thomas, 'Imperial Backwater or Strategic Outpost? The British Takeover of Vichy Madagascar, 1942', The Historical Journal, vol. 39, no. 4 (1996), pp 1049-1074.

8 J Grehan, Churchill's Secret Invasion: Britain's First Large Scale Combined Operations Offensive 1942 (South Yorkshire: Pen \& Sword, 2013).

9 See for instance L Turner, H Gordon-Cumming, and J Betzler, War in the Southern Oceans, 1939-1945 (Cape Town: Oxford University Press, 1961); A Wessels, 'South Africa and the War against Japan 1941-1945', Military History Journal, vol. 10, no. 3 (1996), http://samilitaryhistory.org/vol103aw.html accessed 9 July 2019; DFS Fourie, 'Operation Rose: The only amphibious landing by South African Forces at War, Madagascar, 1942', Military History Journal, vol. 2, no. 1 (1971), http://samilitaryhistory. org/vol021ce.html accessed 9 July 2019; JEH Grobler, 'Die Geallieerde besetting van Madagaskar in 1942, met spesifieke verwysing na die rol van die Unieverdedigingsmag in die operasies, deel 1', Militaria, vol. 7, no. 4 (1977), pp 1-18; JEH Grobler, 'Die Geallieerde besetting van Madagaskar in 1942, deeI 2: die konsolidasietydperk MeiAugustus 1942', Militaria, vol. 8, no. 1 (1978), pp 39-54; JEH Grobler, 'Die Geallieerde besetting van Madagaskar in 1942, deel 3: die toetrede van die Suid-Afrikaanse landmagte en die besetting van Tananarive', Militaria, vol. 8, no. 2 (1978), pp 15-40; JEH Grobler, 'Die Geallieerde besetting van Madagascar in 1942, deel 4: Tamatave, Tulear, en die oorgawe van Annet', Militaria, vol. 8, no. 3 (1978), pp 52-72; JEH Grobler, 'Die Geallieerde besetting van Madagaskar in 1942, deel 5: die lugoffensief, mediese aspekte en Vry Franse oorname', Militaria, vol. 8, no. 4 (1978), pp 69-76. Hynes, The Soldier's Tale, 4-5.

11 Military Service Record Cards and Attestation Forms, Personnel Archive (PA), Personnel Service File 76076V A.T. Bintliff, Department of Defence Archives (DODA).

12 See for instance I van der Waag, 'South African Manpower and the Second World War'. In: Douglas E Delaney, Mark Frost, and Andrew L. Brown, eds. Manpower and the Armies of the British Empire in Two World Wars (Ithaca: Cornell University Press, 2020), pp 299-320. 
Military Service Record Cards and Attestation Forms, PA, Personnel Service File 76076V Bintliff, DODA.

Military Service Record Cards and Attestation Forms, PA, Personnel Service File $76076 \mathrm{~V}$ Bintliff, DODA. Bintliff was found guilty of conduct to the prejudice of good order and military discipline, as defined by Section 40 of the Military Disciplinary Code (MDC).

Military Service Record Cards and Attestation Forms, PA, Personnel Service File 76076V Bintliff, DODA.

EP Kleynhans, 'The First South African Armoured Battle in Italy during the Second World War: The Battle of Celleno - 10 June 1944', Scientia Militaria, vol. 40, no. 3 (2012), p 251.

Military Service Record Cards and Attestation Forms, PA, Personnel Service File 76076V Bintliff, DODA. Bintliff was found guilty of neglecting to obey standing orders, a contravention of Section 11 of the MDC.

Kleynhans, 'The First South African Armoured Battle in Italy', p 257.

Military Service Record Cards and Attestation Forms, PA, Personnel Service File 76076V Bintliff, DODA. Bintliff was awarded the 1939-1945 Star, Africa Star, Italy Star, Defence Medal (British), The War Medal 1939-1945, as well as the Africa Service Medal for his wartime service.

I van der Waag, A Military History of Modern South Africa, (Johannesburg and Cape Town: Jonathan Ball, 2015), p 202.

WS Churchill, The Second World War, Vol. IV:The Hinge of Fate (London: Cassell \& Co, 1950), pp 197-198.

Turner et al, War in the Southern Oceans, pp 131-135, 142-143.

SADF Documentation Service, SA Forces in the Second World War (Pretoria: Directorate Public Relations, n.d.), pp 26-27.

SADF Documentation Service, SA Forces in the Second World War, pp 26-27.

SADF Archives, 'SA Forces in the Second World War', Militaria, vol. 19, no. 3 (1989), pp 33-34.

SADF Archives, 'SA Forces in the Second World War', pp 33-34.

War diaries for July and August 1942, World War II War Diaries (WD), Box 303, File MAD 3/WD, Pretoria Highlanders War Diaries, DODA.

Pte A.T. Bintliff to the Union, 31 July 1942, WD, Box 307, File MAD 9/E9, DODA.

For a detailed discussion on the postal problem in general see war diary, October $1942-$ Appendix 10,WD, Box 303, File MAD 3/WD, Pretoria Highlanders, DODA.

Bintliff to the Union, 31 July 1942,WD, Box 307, File MAD 9/E9, DODA.

Bintliff to the Union, 31 July 1942, WD, Box 307, File MAD 9/E9, DODA.

Bintliff to the Union, 31 July 1942, WD, Box 307, File MAD 9/E9, DODA.

Bintliff to the Union, 31 July 1942, WD, Box 307, File MAD 9/E9, DODA.

War diary, June 1942 - Appendix 10,WD, Box 303, File MAD 3/WD, Pretoria Highlanders, DODA; Medical Aspects of the Campaign in Madagascar, Union War Histories (UWH) (Civil), Box 344, File Campaign in Madagascar, DODA.

Bintliff to the Union, 31 July 1942,WD, Box 307, File MAD 9/E9, DODA.

Bintliff to the Union, 31 July 1942, WD, Box 307, File MAD 9/E9, DODA.

Bintliff to the Union, 31 July 1942, WD, Box 307, File MAD 9/E9, DODA.

Bintliff to the Union, 11 Aug 1942, WD, Box 307, File MAD 9/E9, DODA. 
Bintliff to the Union, 11 Aug 1942,WD, Box 307, File MAD 9/E9, DODA. Bintliff to the Union, 11 Aug 1942,WD, Box 307, File MAD 9/E9, DODA. Bintliff to the Union, 16 Aug 1942, WD, Box 307, File MAD 9/E9, DODA. Bintliff to the Union, 16 Aug 1942, WD, Box 307, File MAD 9/E9, DODA. Bintliff to the Union, 16 Aug 1942, WD, Box 307, File MAD 9/E9, DODA. Bintliff to the Union, 16 Aug 1942, WD, Box 307, File MAD 9/E9, DODA. Bintliff to the Union, 20 Aug 1942, WD, Box 307, File MAD 9/E9, DODA. Bintliff to the Union, 20 Aug 1942, WD, Box 307, File MAD 9/E9, DODA. Bintliff to the Union, 3 Sep 1942, WD, Box 307, File MAD 9/E9, DODA. Bintliff to the Union, 3 Sep 1942, WD, Box 307, File MAD 9/E9, DODA. Bintliff to the Union, 25 Sep 1942, WD, Box 307, File MAD 9/E9, DODA. It is of interest to note that Deon Fourie maintained that it was in fact the Pretoria Regiment that was the only South African unit to be involved in an amphibious landing during the war. He erroneously argues that the South African troops involved in the operations against Tulear, which occurred towards the end of September 1942, claims this honour. See Fourie, Operation Rose for his detailed argument in this regard. A detachment from A Company of the Pretoria Highlanders, however, had the honour of being the first South African forces to be involved in an amphibious operation during the war. These troops were involved in successful occupation of Nossi Bé as part of Operation Esme B on 9 September 1942 - some weeks before the Pretoria Regiment. For confirmation refer to war diary, Sep 1942, WD, Box 303, File MAD 3/WD, Pretoria Highlanders, DODA.

"Nossi Be:The attack and after- recollections and impressions by Pte AT Bintliff", WD, Box 307, File MAD 9/E10 Operations, DODA.

Bintliff, "Nossi Be:The attack and after- recollections and impressions". Bintliff, "Nossi Be:The attack and after- recollections and impressions". Bintliff, "Nossi Be:The attack and after- recollections and impressions". Bintliff to the Union, 25 Sep 1942,WD, Box 307, File MAD 9/E9, DODA. Bintliff to the Union, 25 Sep 1942,WD, Box 307, File MAD 9/E9, DODA. Bintliff, "Nossi Be:The attack and after- recollections and impressions". Bintliff to the Union, 25 Sep 1942, WD, Box 307, File MAD 9/E9, DODA. Bintliff to the Union, 20 Oct 1942, WD, Box 307, File MAD 9/E9, DODA. Bintliff, "Nossi Be:The attack and after- recollections and impressions". 